\title{
THE VALUE OF ISLAMIC TOURISM: PERSPECTIVES FROM THE TURKISH EXPERIENCE
}

\author{
Teoman Duman*
}

\begin{abstract}
The aims of this article are twofold. One is to propose a framework to better understand the terms Islamic tourism and value. Marketing scholars have long studied perceived value and proposed various conceptualisations of the term. However, further explorations are needed to broaden the concept so as to fit the needs and expectations of Muslim consumers. Although Muslims make up one of the largest tourist markets in the world, the perceived value of tourism offerings oriented toward this market has not been clearly defined. Therefore, a framework to present an Islamic view of the concept constitutes the first aim of this article. A second aim is to provide an overview of the halāl tourism market in Turkey. Current developments in the Turkish halāl tourism market and the value of Turkish tourism offerings are discussed in detail. Current issues and proposals for future studies are addressed at the end of the article.
\end{abstract}

\section{Introduction}

The World Islamic Tourism Forum (Kuala Lumpur, 12-13 July 2011) offered a noteworthy effort to advance an area that is closely related to travel activities of all people and of Muslims in particular today. The forum concerns all people because what is most needed today is the knowledge about and understanding of different cultures that interact with each other in every aspect of daily life. Tolerance, respect and mutual sharing are only possible with true understanding of and goodwill toward others. In contemporary life, around one billion people travel internationally for tourism purposes yearly and these travellers share much during their travel activities. Tolerance, respect and mutual sharing are needed more than ever before.

The World Islamic Tourism Forum was concerned with Muslims in particular, because in spite of being members of one of the largest religious communities in the world, they often do poorly in expressing themselves and their way of life to others. Whatever the true reasons for the (as I would consider it) lack of understanding toward

* Teoman Duman is the Deputy Rector for International Relations at the International Burch University, Sarajevo, the capital of Bosnia and Herzegovina. This article is based on the paper presented by him at the World Islamic Tourism Forum (WITF 2011), Kuala Lumpur, 12-13 July 2011, which was jointly organised by the Global Islamic Tourism Organization (GITO) and IAIS Malaysia. The author wishes to thank Mr Recep Zihni for his help and useful comments during the preparation of this article. His valuable support in the process of preparation added much value to the completed effort. 
Muslims today, actions to remove barriers and to establish ties with others are duties of Muslims and non-Muslims alike. Accordingly, efforts such as the aforementioned forum should be highly appreciated.

Technological advancements have brought about massive changes in tourism participation. Compared to several decades earlier, human beings can now travel in large numbers and spend a considerable amount of their time and money for tourism purposes. As one of the results of experience and capacity building, governments and companies can offer high-value products to consumers. In addition, consumers demand better value products because of their experience with products and ease in information gathering (i.e., the internet).

Value in consumption has become the key term recently because it results in consumer satisfaction and loyalty. ${ }^{1}$ In broad terms, consumers value products based on what they get versus what they give. ${ }^{2}$ Although academics have gathered considerable theoretical knowledge concerning the conceptualisation of perceived value, research about its true meaning applicable to different customer groups is still lacking. In other words, we know in general that consumers value products based on quality, price and affective benefits. ${ }^{3}$ However, we still don't know what makes up value for different customer groups that come from various cultural backgrounds. The question is therefore how to define perceived value for halāl tourism consumption and how it is different from other types of tourism consumption.

\section{Definition of the Concept of Islamic Tourism}

Tourism is a complex phenomenon and it is a challenging task to offer a succinct definition of this concept. ${ }^{4}$ According to the World Tourism Organisation (WTO), "Tourism comprises the activities of persons travelling to and staying in places outside their usual environment for not more than one consecutive year for leisure, business and other purposes not related to the exercise of an activity remunerated from within the place visited." ${ }^{5}$ Tourism, therefore, consists of the short term movement of people to destinations outside their usual environment and their activities. ${ }^{6}$ Tourism is inherently related to three types of activities: ${ }^{7}$ travelling away from one's home for 24 hours, using one's leisure time to travel and take holidays, and travelling for business. ${ }^{8}$ Furthermore, three qualities make up the essence of tourism: the movement of people, a sector of the economy or the industry; a broad system of interacting relationships of people, given their need to travel outside their communities; and services that attempt to respond to these needs by supplying products. ${ }^{9}$

Apparently, tourism is not a new phenomenon, but technological advancements especially in jet aircrafts contributed significantly to the concept. The world has experienced mass movements of people during the past century, and tourism has been discussed as a social force and a reality in today's modern life. 
Some of the difficulties scientists and practitioners have had in studying tourism are the recognition of it as an area or subject, conceptualisation due to its multidisciplinary nature, confusion about related terminology (e.g. ecotourism), reductionism (oversimplification) of its scope, rigour or inconsistency in defining the concept and different approaches taken by the academy and practice. ${ }^{10}$ The same difficulties apply to the conceptualisation of Islamic tourism today.

In brief, tourism is a complex phenomenon with sociological, behavioural, economical, political, cultural and environmental dimensions influencing every aspect of life in modern societies and scientists have difficulties in drawing its borders. Much has been achieved in tourism studies in 1990s. A number of books and academic journals have been published in tourism, hospitality and related areas. However, it is hard to make the same conclusion for studies related to tourism and its relationship with the religion of Islam and Islamic consumption. Notable writers have made invaluable contributions to approaching the concepts related with tourism and Islam but as an academic area it seems still in its infancy. ${ }^{11}$ The Islamic Tourism magazine is the only periodical to my knowledge that devotes its name to Islam and tourism (www.islamictourism.com). A number of authors have presented views about concepts related to Islam and tourism in this magazine. Also, the Global Islamic Tourism Organisation (GITO) has given academics and practitioners a chance to present views about Islam and tourism in its international conferences.

Henderson points out the definitional ambiguities with regard to the concept of Islamic tourism. She distinguishes between Islamic tourism, non-Islamic tourism and un-Islamic (anti-Islamic) tourism. ${ }^{12}$ According to Henderson, Islamic tourism covers all product development and marketing efforts designed for and directed at Muslims whereas non-Islamic tourism represents product development and marketing efforts designed for and directed at non-Muslims.

Some of the definitions of the concept of Islamic tourism found in literature are presented in Table 1. The following section will elaborate on the definition of Islamic tourism and provide a motivational approach to the concept.

Table 1 Previous Definitions of 'Islamic Tourism'

\begin{tabular}{ll}
\hline Authors & Definitions \\
\hline Henderson & All product development and marketing efforts designed \\
$(2010)^{14}$ & for and directed at Muslims. Motivations are not always or \\
& entirely religious. Participants could be pursuing similar leisure \\
& experiences as non-Muslims, albeit within parameters set by \\
& Islam, and destinations are not necessarily locations where the \\
& shari'ah or full Islamic law is enacted.
\end{tabular}


Ala-Hamarrneh The economic concept for Islamic tourism is an extension and $(2011)^{15} \quad$ expansion oriented concept which focuses on the importance of intra-Muslim and intra-Arab tourism in terms of inclusion of new tourist markets and tourist destinations.

The cultural concept for Islamic tourism includes visions and ideas that outline the inclusion of Islamic religious-cultural sites in tourism programs with pedagogical and self-confidencebuilding elements.

The religious-conservative concept for Islamic tourism has not yet been theoretically articulated. But various opinions and remarks in the discussions on the future of tourism in the Arab and Islam worlds as well as some practices of hotel management indicate that articulations and implementations are just a matter of time.

Henderson Tourism mainly by Muslims, although it can extend to $(2009)^{16}$ unbelievers motivated by Islam to travel, which takes place in the Muslim world.

Shakiry $(2006)^{17}$ The concept of Islamic tourism is not limited to religious tourism but extends to all forms of tourism except those that go against Islamic values.

Hassan In its narrow sense, it may mean religious tourism (visiting $(2007)^{18}$ shrines all over the Islamic world). But in its wide sense, it is the type of tourism that adheres to the values of Islam. Most of these values are shared with other religious and non-religious beliefs (for example the ethical code promoted by World Tourism Organisation). It calls for respect for local communities and the local environment, benefiting the locals, acting with decency and learning about other cultures.

Hassan Islamic tourism means a new ethical dimension in tourism. It $(2004)^{19} \quad$ stands for values generally accepted as high standards of morality and decency. It also stands for the respect of local beliefs and traditions, as well as care for the environment. It represents a new outlook on life and society. It brings back values to the central stage in an age where consumerism is rife and everything is available for use and abuse in the most selfish way. It also encourages understanding and dialogue between different nations and civilisations and attempts to find out about the background of different societies and heritages. 
Dogan $(2011)^{20}$ Islamic tourism covers tourism activities by Muslims in seaside destinations for the purposes of relaxation and entertainment in hospitality enterprises that apply Islamic principles.

\section{A Proposed Definition of Islamic Tourism: Motivational Perspective}

Definitions of Islamic Tourism presented in Table 1 give reference to the participants of the activity (e.g., Muslims), locations (e.g., Islamic destinations), products (e.g., accommodations, food and beverage), dimensions (economic-cultural-religious) and management of the service production process (e.g., marketing and ethics).

These definitions, in general, give little attention to the motives that initiate travel. Motivations are especially important in the case of Islam because every deed starts with intentions and has results accordingly. In a famous hadìth, Prophet Muhammad said, "The reward of deeds depends upon the intentions and every person will get the reward according to what he/she has intended." 20 The act of travel in Islam is considered a purposeful activity which puts great emphasis on Islamic motivations as acting in the cause of God ( $f \grave{i}$ sabill-Allāh), submission to the ways of God (through hajj and ${ }^{c} u m r a h$ ), realisation of the smallness of man and the greatness of God, encouraging and strengthening the bond of silat al-rahim (Muslim fraternity) and conducting business. ${ }^{21}$ Muslims are encouraged to achieve physical, social and spiritual goals by travelling. ${ }^{22}$

From this perspective, Islamic tourism can be defined as tourism activities by Muslims that originate from Islamic motivations and are realised according to shar $\bar{l}^{c}$ ah-principles. These activities can be within the scope of the hajj, the ${ }^{c} u m r a h$, silat al-rahìm, fì sabìl-Allāh (acting in the cause of God) and others referenced by the Qur'ān and by the teachings of Prophet Muhammad. Other activities may comprise those that are held "to appreciate the greatness of God through observing the signs of beauty and bounty of His creations which can be seen everywhere, both in the realms of past and present." ${ }^{23}$ In this regard, travelling for such purposes as health (relaxation), education (learning-teaching-information sharing), and awareness of other cultures, education and business are all considered within Islamic motivations to travel referenced in the Qur'ān and in the Sunnah. ${ }^{24}$ In this view, for a tourism activity to be called Islamic, it should originate from the motivations referenced in the main sources of Islam.

If we apply the above definition to the WTO definition, then, Islamic tourism can be defined as the activities of Muslims travelling to and staying in places outside their usual environment for not more than one consecutive year for participation in those activities that originate from Islamic motivations which are not related to the exercise of an activity remunerated from within the place visited. 
This definition of Islamic tourism differs from the general definition of tourism in that it differentiates participants as Muslims and motivations to travel as Islamically acceptable purposes. An undisputed condition on Islamic activities is that they have to be conducted according $\operatorname{sharl}^{2} a h$-principles which make these activities acceptable (halāl) in Islam. ${ }^{25}$

\section{Islamic Tourism as a Commercial Activity: Halāl Tourism}

The discussion presented about Islamic tourism so far has taken a motivational perspective toward the tourism activity. Islamic tourism as an economic activity can be separated from this discussion and the industry that serves Muslim tourists may be defined in commercial terms. In Islamic literature, a general term for religiously acceptable is halāl and it usually refers to the consumption and utilisation of material things for Muslims. ${ }^{26}$ The way to utilise and consume all the blessings is mubāh and termed haläl in Islam. ${ }^{27}$ In other words, consumption and utilisation of things that are not forbidden by the Qur'ān and the Sunnah (sayings and deeds of the Prophet Muhammad) are halāl in Islam. ${ }^{28}$ The opposite of the term is harām and it denotes unacceptable consumption and utilisation of things. A Muslim is therefore expected to benefit from halāl things and to abstain from the harām. From this point of view, categorisation of tourism-related goods and services that are designed, produced and presented to the markets according to Islamic rules ( $\left.\operatorname{shari}^{c} a h\right)$ can be considered under halāl tourism. Such use of the terminology about touristic goods and services is already common. For example, the terms halāl trips, hotels, airlines and foods are frequently used in sectoral terminology. ${ }^{29}$

\section{Islamic Tourism Decision Making and Perceived Value for Halāl Tourism Products}

Research in consumer behaviour shows that the entire consumer decision-making process can be explained in four distinct stages. ${ }^{30}$ The process is typically initiated by felt needs or motivations, continues with selection of products (e.g., information collection, evaluation of alternatives and choices), experience with or consumption of products and post-purchase evaluation and future decisions. Components of the decision-making process are illustrated in Figure 1. As shown in the figure, components of these stages for the consumption of tourism products include;

- Motivations: The motivation to participate in tourism activity can be generic tourism motivations (e.g., conducting business, visiting friends or relatives, pursuing other personal business activities (e.g., shopping) and pleasure ${ }^{31}$ ), specific Islamic motivations (e.g., acting in the cause of God (fì sabìl-Allāh), submission to the ways of God (through hajj and ${ }^{c} u m r a h$ ), realisation of the smallness of man and the greatness of God, encouraging and strengthening 
the bond of silat al-rahim (Muslim fraternity), conducting business ${ }^{32}$ ) or non-Islamic (Islamically unacceptable) motivations. Most generic motivations are common for Muslims and non-Muslims. However, certain motivations for tourism which provoke pure hedonism, permissiveness, lavishness, servitude, foreignness, etc., are not acceptable according to Islamic doctrine ${ }^{33}$ and these motivations can be considered non-Islamic motivations. For example, tourism as "sex tourism" 34 and "wine tourism" 35 is unacceptable and considered harām in Islam. Examples of generic and Islamic tourist motivations are given in Table 2.

- Decision-making: Actual decision-making includes information gathering, evaluation of alternatives and making choices. In the case of Islamic tourism, actual decisions are made based on $\operatorname{shari}^{\top} a h$ principles, which influence subsequent stages in the process.

- Service-consumption: Consumption of products includes affective aspects (e.g., hedonics), monetary aspects, non-monetary aspects (e.g., time, effort and psychological discomfort) and product quality aspects. ${ }^{36}$

- Post-purchase evaluation: Post-purchase evaluation includes perceived value, satisfaction and behavioural intentions (e.g., recommending, complaining, revisiting intentions). ${ }^{37}$

Table 2 Examples of generic and Islamic tourist motivations

\begin{tabular}{lll}
\hline Motivations & Sources \\
\hline Generic & Conducting business, visiting friends or Goeldner and \\
Motivations & relatives, pursuing other personal business & Ritchie $(2006)^{39}$ \\
& activities (i.e. shopping) and pleasure. \\
& Experiencing culture, pleasure-seeking, Kozak (2002) ${ }^{40}$ \\
& fantasy, relaxation, physical participation. \\
& - Relaxing mentally, discovering new places Ryan and \\
& and things, avoiding the hustle and bustle \\
& of daily life, relaxing physically, being in $(1998)^{41}$ \\
& a calm atmosphere, increasing knowledge, \\
& having a good time with friends, being with \\
& others, building friendships with others, using \\
& imagination, gaining a feeling of belonging, \\
& challenging personal abilities, using abilities \\
& and skills in sports, developing close \\
& relationships.
\end{tabular}


- Climate, relaxation, adventure, personal Bansal and reasons (i.e. nostalgia), educational motives. Eiselt (2004) ${ }^{42}$

Islamic Acting in the cause of God (fi sabìl-Allāh), Din (1989)43

Motivations submission to the ways of God (through hajj and 'umrah), realisation of the smallness of man and the greatness of God, encouraging and strengthening the bond of silat al-rahim (Muslim fraternity), conducting business.

- Seeking health (relaxation), education Aglamaz (learning-teaching-information sharing- (2009) ${ }^{44}$ visiting scientists), realisation of other cultures, business.

- Promoting Islam (tabligh), seeking scientific Kusursuz knowledge, educating others, working for $(2011)^{45}$ halāl earnings, taking lessons from past.

One of the critical aspects of the consumer decision-making process is consumers' evaluation of value of products. There is a general consensus in consumer behaviour research that consumer satisfaction and future behavioural intentions are positively influenced by their perceptions of value. ${ }^{45}$ In making value evaluations, consumers typically compare what they receive (i.e., benefits) with what they have given up (i.e., price and non-monetary sacrifice).$^{46}$

Consumption of tourism products has distinct characteristics because tourism involves a longer time due to travel and usually entails higher overall costs. Therefore, tourists usually spend considerable time on evaluating their experiences and demand high value for future participation. High value tourism products are usually emotionally satisfactory, reasonably-priced, of high quality and require little physical and psychological effort. Consumers usually refer back to their expectations when making satisfaction and value evaluations. ${ }^{47}$ Expectations are formed with consumer motivations and consumers expect to find benefits congruent to their initial motivations.

Evaluation of the value of tourism products in the case of Islamic tourism participation entails a completely different process due to the requirements of Islam. These requirements are called $\operatorname{sharl}^{c} a h$-principles and at the simplest level these principles "prohibit adultery, gambling, consumption of pork and other harām (forbidden) foods, selling or drinking liquor and dressing inappropriately." ${ }^{48}$ In addition, a typical Muslim is expected to do regular prayers in clean environments and fast in Ramadan. In Islamic teachings, Muslims are also expected to abstain 
from profligate consumption and indulgence. ${ }^{49}$ Islamic principles are requirements for every Muslim, and sensitivity toward application of these principles is important because religious deeds are not acceptable if they are not conducted appropriately. Therefore, the participation of Muslims in tourism activities requires acceptable ( halāl) goods, services and environments. The differences between Muslim and nonMuslim tourist participation in tourism with regard to value perceptions are illustrated in Figure 1. As shown in the figure, $\operatorname{sharit}^{c} a h$-compliance should be a pre-requisite for high value tourism experiences for Muslims.

\section{Halāl Tourism and Turkish Experience}

In this part of the paper, my purpose is to present the current situation in Turkey with respect to halāl tourism industry. As noted previously, all the goods and services of the tourism industry designed according to Islamic principles and offered to Muslim markets in Turkey are considered part of halāl tourism in Turkey.

\section{An Overview of the Turkish Tourism Industry}

Official tourism statistics provided by Turkish Ministry of Culture and Tourism show that Turkey attracted over 28 million tourists in 2010. Tourism receipts exceeded US $\$ 21$ billion and average tourist spending was around US\$630..$^{50}$ For a long time, Turkey has been one of the top ten tourist destinations in terms of tourist arrivals. Political stability of the country in 2000s has resulted in improvements in many areas including infrastructure, international relations and event management, which all had a pivotal impact on tourism development. According to projections, the country is expected to increase tourist numbers to 63 million tourists and tourism earnings to US $\$ 86$ billion by $2023 .^{51}$

\section{Turkish Tourism Products}

Turkey is quite rich in tourism potential. Its geographic location, climate, the multicultural nature of its demographics and its diverse history make it one of the most attractive destinations in the world. Among the types of tourism actively pursued that are listed by the ministry of Culture and Tourism in Turkey are seasun-sand, health and thermal (hot-spa), winter, highland, cave, hunting, event, golf, youth, yacht, botanic, silk road faith, air sports, mountaineering, rafting, diving and bird watching.

Currently, Turkey has a touristic bed capacity of around 600,000 and 2,600 accommodation facilities. These numbers are up from a bed capacity of 56,000 and 500 facilities in 1980. Antalya, Istanbul, and Mugla are the three major tourism cities in Turkey. These cities accommodate around $50 \%$ of international visitors to the country. ${ }^{52}$ 
Figure 1 A Proposed Model of Perceived Value for an Islamic Tourism Decision-Making Pocess

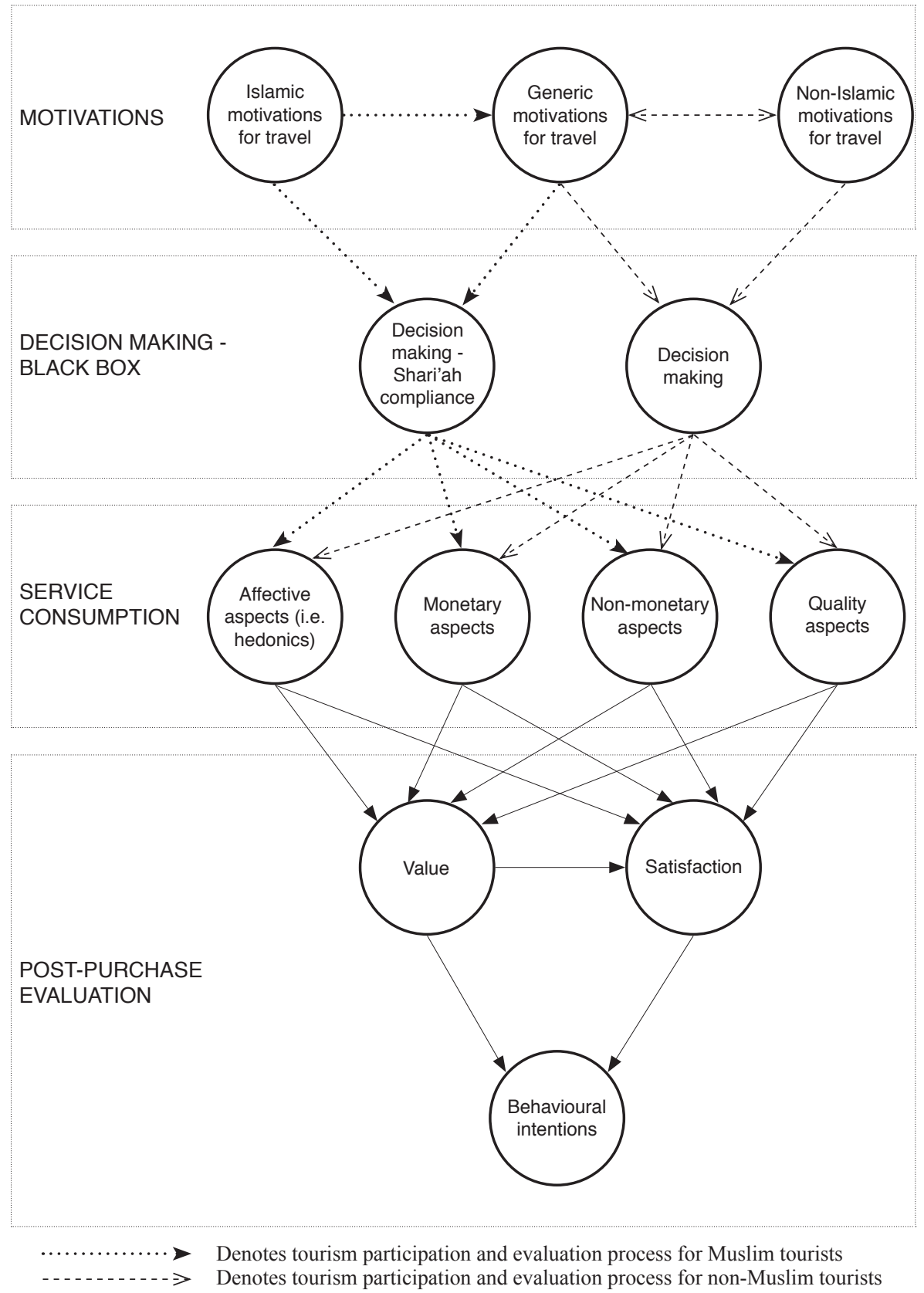




\section{An Overview of Halāl Tourism Industry in Turkey}

\section{A Historical and Political Perspective on Halāl Tourism Industry in Turkey}

The roots of contemporary tourism in Turkey go back to the establishment of the Tourism and Promotion Ministry in 1963. In the 1960s and 1970s, very limited signs of organised tourism activity existed in Turkey. The governmental effort in these years was mostly spent on planning..$^{53}$ The start of mass tourism activity was with famous Tourism Incentive Act in 1982. The period from the 1980s until 1992 is remembered in connection with Prime Minister Turgut Özal and his party, ANAP. Much of planning, infrastructure, legislation (i.e. incentives) and promotion were accomplished during these years with Özal and his ANAP party. The 1990s through 2012 were marked by political instability and economic downturn which resulted in the increase of mass tourism activity with all-inclusive vacations. A massive tourist influx to popular seaside destinations was experienced during these years from the European and Russian markets. The last decade (2002-2012) has seen political stability and economic development. These years were marked by a new wave of tourism-planning that included a tourism diversification policy where different types of tourism were encouraged in every part of the country. A review of the recent tourism development history in Turkey is presented in Table 3.

Table 3 Review of the Recent Tourism Development History in Turkey

\begin{tabular}{|c|c|c|c|c|}
\hline & $\begin{array}{l}\text { Before } \\
1980 \mathrm{~s}\end{array}$ & 1980-1992 & 1992-2002 & $2002-2011$ \\
\hline $\begin{array}{l}\text { Political } \\
\text { environment }\end{array}$ & $\begin{array}{l}\text { - Political } \\
\text { turmoil }\end{array}$ & $\begin{array}{ll}\text { - } & \text { Turgut Özal- } \\
& \text { ANAP } \\
\text { - } & \text { Political } \\
\text { stability }\end{array}$ & $\begin{array}{l}\text { - Political turmoil } \\
\text { - Economic } \\
\text { downturn }\end{array}$ & $\begin{array}{l}\text { Recep Tayyip Erdoğan, } \\
\text { AKP } \\
\text { - Political stability } \\
\text { - Economic development } \\
\text { - Rising middle class }\end{array}$ \\
\hline $\begin{array}{l}\text { Scope of } \\
\text { tourism } \\
\text { activity }\end{array}$ & $\begin{array}{l}\text { Very } \\
\text { limited } \\
\text { tourism } \\
\text { activity }\end{array}$ & $\begin{array}{l}\text { - Establishment } \\
\text { of tourism } \\
\text { legislation } \\
\text { - Planning and } \\
\text { infrastructure } \\
\text { - Upsurge } \\
\text { in tourist } \\
\text { numbers } \\
\text { - Recognition } \\
\text { in European } \\
\text { markets }\end{array}$ & $\begin{array}{l}\text { - Building of } \\
\text { superstructure } \\
\text { - Rising promotion } \\
\text { activites } \\
\text { - Increasing supply } \\
\text { - Popularity in } \\
\text { Russian markets } \\
\text { - Increasing tourist } \\
\text { - numbers } \\
\text { Popularity of all- } \\
\text { inclusive vacations } \\
\text { - Decreasing tourism } \\
\text { earnings }\end{array}$ & $\begin{array}{l}\text { - Increasing tourism } \\
\text { supply and demand } \\
\text { - Tourism product } \\
\text { diversification } \\
\text { - Increasing thermal } \\
\text { tourism supply } \\
\text { - Holistic tourism } \\
\text { planning (Turkish } \\
\text { Tourism Strategy 2023) } \\
\text { - Upsurge in participation } \\
\text { of Muslims in tourism } \\
\text { activity }\end{array}$ \\
\hline
\end{tabular}


The halāl tourism industry products that attract mainly conservative Muslims were presented to the tourism markets mainly after 2002 with the coming of Erdoğan and his political party, AKP. The number of seaside hotels and resorts supplying halāl tourism concepts increased from 5 to 39 following the AKP take-over of the government after the 2002 elections. ${ }^{54}$ Critics in Turkey argue that the increase in haläl tourism activity in Turkey is mainly due to the economic and political progress of conservative Muslims in Turkey. ${ }^{55}$ The AKP is blamed for creating an alternative way of life as opposed to the Western style which includes the Islamic way of holiday making. ${ }^{56}$

Halāl tourism was also discussed in various platforms in the international arena. Discussions about halāl tourism have gained support from member countries in the Economic and Commercial Cooperation of the Organisation of the Islamic Conference (ISEDAK - comcec.org). One of the areas recommended for support in the 2007 conference was "Islamic Halal Tourism". The magnitude of the Islamic tourism market was also mentioned at the World Travel Market fair in London in 2007. In one occasion, it was noted in the press that the president of the Independent Industrialists and Businessmen's Association (MUSIAD) proposed an Islamic Tourism Free Zone during Saudi Arabia's King Fahd's visit to Turkey. ${ }^{57}$

\section{The Legal Status of Halāl Tourism Products in Turkey}

The standardisation and certification of tourism enterprises in Turkey are ruled by the Ministry of Culture and Tourism. The latest directive on this issue was approved by the Council of Ministers (10 May 2005, no. 2005/8948) and published in the official Gazette (21 June 2005, no. 25852). The current directive does not refer directly to the selling of alcoholic beverages. But it does require four-star holiday villages to have an open or closed bar, and five-star holiday villages to have a discotheque or a night club on the premises. The requirement to have a bar on the premises in two-plus star hotels was removed in this new directive.

The hotels that employ the haläl tourism concept are known to obey all the legal requirements of the ministry directives but use hotel facilities compatible with halāl tourism. For example, these hotels do not sell alcoholic beverages in the bars and use the discotheque and night clubs as prayer rooms. ${ }^{58}$ In addition, these hotels separate pool and beach facilities for men and women, apply dress codes in certain areas, do not allow opposite gender children ( 6 and above) in swimming facilities, ban photographing in swimming facilities, encourage social programs with Islamic content and market through certain distribution channels. ${ }^{59}$

The above-mentioned characteristics of the haläl hotels provoked some criticism from the sector representatives in that the standards used in these hotels create unlawful discrimination between domestic and foreign tourists, genders, bachelors and married tourists, alcohol-consuming tourists and others. ${ }^{60}$ These hotels are 
especially criticised for using public beaches for their own purposes by creating private spaces for men and women.

\section{Major Types of Halāl Tourism Activities and Resorts}

The accommodation facilities that cater to the halāl tourism industry in Turkey can be categorised into two groups. One of these groups consists of seaside facilities. These facilities have been popular since the last decade or so and they represent a fairly new concept for Turkish tourism. As mentioned previously, the number of these facilities increased from 5 to 39 in just five years, and this trend is still gaining in popularity. The other group includes hot-spa (thermal) facilities which cater to both health tourism and entertainment tourism. As a concept, hot-spa tourism is as old as humanity and these facilities have been serving Turkish tourists for many years.

Table 4 shows popular terminology used in web pages for hospitality enterprises that target Muslim populations.

Table 4 Terminology Used by Hospitality Enterprises to Describe Vacations and Tourism Products to Attract Muslim Tourists in Turkey

\begin{tabular}{ll}
\hline Terminology in Turkish & Terminology in English \\
\hline Islamitatilyerleri & Islamic vacation destinations \\
Islamioteller & Islamic hotels \\
Muhafazakaroteller - tatilköyleri - tatil & Conservative hotels - resorts - vacation \\
Alternatiftatil - oteller & Alternative hotels - vacations \\
Tesettürlüoteller & Veiled (covered) hotels \\
Dinioteller & Religious hotels \\
Islamitermaloteller & Islamic hot-spa (thermal) hotels \\
Islamikaplicalar & Islamic hot-spas \\
Kaplicalar & Hot-spas \\
Dindartatil & Religious vacations \\
İckisizoteller & Alcohol-free hotels \\
Bay-bayanayrlhavuzluoteller & Hotels with separate pools for men and women \\
Islamikonseptliotel & Hotels with Islamic concept \\
\hline
\end{tabular}

Although there are no statistical data in Turkey that show the capacity of hospitality enterprises using the halāl tourism concept, an overall figure is given in Figure 2 based on internet data. The hotels and their capacities are identified from internet sources, and total capacity for these hotels is given in Figure 2. The numbers in Figure 2 include both seaside and hot-spa facilities. As shown in the figure, hospitality enterprises using halāl tourism concept make around $5.6 \%$ of the total bed capacity in Turkey. This figure is very limited considering the totality of the Muslim tourist market in Turkey. 
Figure 2 A Categorisation of Hospitality Enterprises in Turkey Based on Consumer Profiles

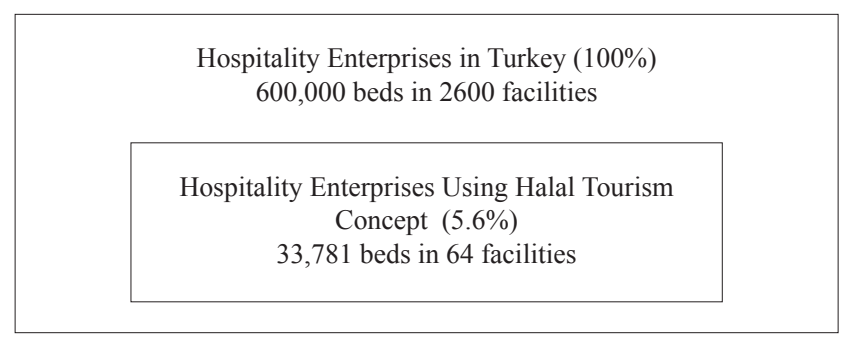

Seaside Facilities: The seaside facilities that claim to apply halāl tourism concept are given in Table 5. ${ }^{61}$ As shown in the table, five of these facilities opened before 2002. The rest of the facilities were launched after 2002. Fourteen of the facilities are located in the vicinity of Alanya, a famous tourism resort, and all the facilities have a 3 -star or above rating. The largest of these facilities is Ihlas Armutlu in Yalova which is in close proximity to the large Istanbul market.

Hot-Spa (Thermal) Resorts: Turkey is rich with hot-spa (thermal) resources. Potentially, it is considered among seven countries in the world and the top one in Europe. Culturally, the use of thermal water dates back to centuries. Today, 240 facilities serve tourists for health tourism and other purposes. Fifty-one cities promote hot-spa tourism as part their tourism potential. ${ }^{62}$ Turkey's tourism diversification strategy in 2000s resulted in 22 new hot-spa facilities and increased the number to 240 with around a 30,000 bed capacity. ${ }^{63}$ Table 6 lists hot-spa facilities in Turkey targeting Muslim tourists. As seen in the table, 20 facilities with a 11,080 bed capacity use the halāl tourism concept in hot-spa tourism in Turkey.

\section{Market Description and Consumer Behaviour}

Market Description: The markets for the halāl tourism facilities in Turkey can be categorised into three broad groups. The first group is Turkish citizens living and working in European countries. Around 2.4 million Turkish citizens live in Europe and they constitute a lucrative market for these facilities. Indeed, the capital for new halāl tourism facilities in Turkey is attributed to coming from corporations established by Turkish citizens living in Europe. ${ }^{64}$ The largest of these corporations include Kamer, Kombassan, Yimpaş, Selva, Ilay and Atlas. A second market for halāl tourism facilities includes upscale customers with conservative Islamic lifestyles. Turkish upscale Muslim customers have usually spent their leisure time in their private residences in tourist areas but now attend modern haläl facilities. Although the upscale customers make up the main target market for halāl tourism 
facilities, recent economic developments in Turkish economy have given middle class customers a chance to spend vacations in these facilities. Currently, there is no research study available (to the researcher's knowledge) about the customer profiles of halāl tourism hotels in Turkey. A third market for halāl facilities in Turkey is foreign Muslim tourists, especially from Middle Eastern countries. Turkey's new haläl facilities have become popular in Muslim countries recently and created a lot of news in the Turkish media.

Consumer Behaviour: Research on halāl tourism consumer markets is very limited in Turkey. An analysis of customer comments on popular haläl tourism websites in Turkey shows that despite general satisfaction with the haläl tourism concept in the facilities, a number of issues and concerns still remain to be resolved. Customers usually complain about high prices, low quality of service and use of beaches in common with non-Muslim tourists. The perception of high prices and low quality of service are related to the seasonal nature of tourism activity. Hotels are usually full during summer months and they raise prices to cover costs. In addition, managing full capacity with seasonal personnel also creates difficulties for management of these hotels.

One of the concerns raised by customers is related to hotels that serve multiple customer groups. The increasing demand for halāl tourism has encouraged some hotels to change their standards recently although they may not apply Islamic rules to the fullest in their services. For example, some customers have argued that the hotel opens up its swimming pools for common use although it promoted its concept as halāl tourism. Table 7 shows the survey results from one of the halāl tourism web sites in Turkey. As seen in the table, overall respondents find halāl tourism hotels "Islamically acceptable", consider such a vacation as a need, give priority to prices and cleanliness in hotel selection, and find prices in these hotels rather expensive.

Table 5 Selected Seaside Hospitality Enterprises in Turkey Targeting Muslims

\begin{tabular}{lclrr}
\hline Facility Name & Foundation & Location & $\begin{array}{c}\text { \# of } \\
\text { Bedrooms }\end{array}$ & \# of Beds \\
\hline 1. Caprice Palace & 1996 & Didim/Aydın & 491 & 1400 \\
2. YeniMeltem & 1998 & Çesme/Izmir & 70 & 200 \\
3. Club KaraburunSelva & 1999 & Alanya/Antalya & 150 & 750 \\
4. Sah Inn Suit & 1999 & Alanya/Antalya & 112 & 440 \\
5. Çam\&Çam & 2001 & Kusadasi/Aydın & 24 & 100 \\
6. Fistikli Çiçekevler & 2002 & Yalova & 29 & 100 \\
7. Club Familia & 2004 & Çesme/İzmir & 297 & 1000 \\
8. IhlasArmutlu & 2004 & Yalova & 1686 & 6000 \\
9. Beyza Hotel & 2005 & Altinoluk/Balıkesir & 60 & 220
\end{tabular}




\begin{tabular}{|c|c|c|c|c|}
\hline 10. Club Asya & 2006 & Karaburun/İzmir & 88 & 250 \\
\hline 11. Burc Club & 2006 & Selçuk/İzmir & 150 & 450 \\
\hline 12. Club Samira & 2006 & Alanya/Antalya & 102 & 400 \\
\hline 13. Eda Garden & 2006 & Çesme/İzmir & 110 & 400 \\
\hline 14 .DemirtasHuzur & 2006 & Alanya/Antalya & 58 & 174 \\
\hline 15. Bakar Suit Otel & 2006 & Kusadasi/Aydın & 80 & 350 \\
\hline 16. Ilay Alanis & 2006 & Alanya/Antalya & 80 & 250 \\
\hline 17. YesilözOtel & 2006 & Side/Antalya & 76 & 270 \\
\hline 18. Ionia Otel & 2006 & Çesme/İzmir & 30 & 100 \\
\hline 19. Slg Tulip SelvaOtel & 2006 & Alanya/Antalya & 95 & 320 \\
\hline 20. Sah Inn Paradise & 2007 & Kumluca/Antalya & 404 & 1400 \\
\hline 21. IlayAtlibayDelüxe & 2007 & Alanya/Antalya & 197 & 1000 \\
\hline 22. Hare Otel & 2007 & Alanya/Antalya & 64 & 144 \\
\hline 23. Bera Otel Alanya & 2007 & Alanya/Antalya & 332 & 1200 \\
\hline 24. Club Fiesta & 2007 & Alanya/Antalya & 107 & 340 \\
\hline 25. Club Hotel Berr & 2007 & Alanya/Antalya & 117 & 354 \\
\hline 26. Ispa Belvu Resort & 2007 & Kemer/Antalya & 64 & 200 \\
\hline 27. Yasmak Otel & 2007 & Yalova & 150 & 32 \\
\hline 28. Liva Orkinos & 2007 & Erdek/Balıkesir & 56 & 220 \\
\hline 29. Körfez T.K. & 2007 & Edremit/Balıkesir & 204 & 1010 \\
\hline 30. DörtMevsim T.K. & 2008 & Sile/istanbul & 40 & 200 \\
\hline 31. Belvü Resort Otel & 2008 & Kemer/Antalya & 40 & 125 \\
\hline 32. Ilay Patara & 2008 & Kalkan/Antalya & 135 & 335 \\
\hline 33. Ionya Otel & 2008 & Çesme/İzmir & 30 & 130 \\
\hline 34. ÖnemliHisarOtel & 2009 & Bodrum/Muğla & 120 & 480 \\
\hline 35. Olive Garden Otel & 2009 & Fethiye/Muğla & 58 & 140 \\
\hline 36. Karye Club & 2009 & Side/Antalya & 20 & 90 \\
\hline 38. ElizanOtel & 2009 & Fethiye/Muğla & 52 & 135 \\
\hline 39. Bal Beach Otel & 2009 & Bodrum/Muğla & 50 & 200 \\
\hline 40. Silver Pine Otel & 2009 & Fethiye/Muğla & 46 & 110 \\
\hline 41. Tugra Suit Otel & 2009 & Alanya/Antalya & 112 & 450 \\
\hline 42. HamitogluOtel & 2010 & Alanya/Antalya & 85 & 250 \\
\hline 43. RizomTatilKöyü & 2010 & Yalova & 159 & 600 \\
\hline \multirow[t]{2}{*}{ 44. Yunuslar T.K. } & 2010 & Bodrum/Muğla & 60 & 264 \\
\hline & & Total & 6372 & 22701 \\
\hline
\end{tabular}

Note: Categorisation of hotels is based on web-site descriptions.

Sources: Doğan (2011); islamitatil (2011); tesetturluoteller (2011) and islamioteller (2011). 
Table 6 Selected hot-spa hospitality enterprises in Turkey targeting Muslims

\begin{tabular}{|c|c|c|c|c|}
\hline Facility Name & Foundation & Location & $\begin{array}{c}\text { \# of } \\
\text { Bedrooms }\end{array}$ & \# of Beds \\
\hline 1. AsyaTermalTatilKöyü & 2004 & $\begin{array}{l}\text { Kizılcahamam/ } \\
\text { Ankara }\end{array}$ & 544 & 2000 \\
\hline 2. TermalyaOtel & NA & Kozaklı/Nevşehir & 137 & 356 \\
\hline 3. KorelTermalOteli & 2006 & Afyonkarahisar & 331 & 800 \\
\hline 4. Rosa Resort Oteli & 2005 & Kozaklı/Nevşehir & 230 & 864 \\
\hline 5. AdramisTermalOtel & NA & Edremit/Balıkesir & 66 & 135 \\
\hline 6. GönenKaplıcaOteli & NA & Gönen/Balıkesir & 380 & 785 \\
\hline 7. GönlüferahOteli & 1910 & Bursa & 90 & 182 \\
\hline 8. Kozaklı Grand Termal & 2007 & Kozakl1/Nevşehir & 152 & 375 \\
\hline 9. AsosTermalOtel & 2008 & Kozaklı/Nevşehir & 255 & 1200 \\
\hline 10. Ottoman Thermal Palace & 2008 & Antakya & 252 & 650 \\
\hline 11. NehirTermalOtel & 1999 & Yoncal1/Kütahya & 62 & 150 \\
\hline 12. EmetTermalOtel & 2008 & Kütahya & 123 & 198 \\
\hline 13. KörfezTatilBeldesi & 2006 & Güre/Balıkesir & 200 & 1035 \\
\hline 14. EşinTermal Palace & 2011 & Didim/Aydın & 76 & 400 \\
\hline 15. Gönen & NA & Gönen/Balıkesir & 336 & 800 \\
\hline 16. Yalova & NA & Yalova & 101 & 220 \\
\hline 17. SoydanTermalOtel & NA & $\begin{array}{l}\text { Gazlıgöl/ } \\
\text { Afyonkarahisar }\end{array}$ & 56 & 150 \\
\hline 18. Tuzla İçmelerOteli & 1990 & Tuzla/Istanbul & 46 & 100 \\
\hline 19. Diva Ibis & 2008 & Kozaklı/Nevşehir & 179 & 540 \\
\hline \multirow[t]{2}{*}{ 20. KuzulukTermalOtel } & NA & Kuzuluk/Sakarya & 65 & 140 \\
\hline & & Total & 3616 & 11080 \\
\hline
\end{tabular}

Note: Categorisation of hotels is based on web-site descriptions. Sources: Islamitatil (2011); tesetturluoteller (2011) andislamioteller (2011).

Table 7 Consumer perceptions about halāl tourism and products

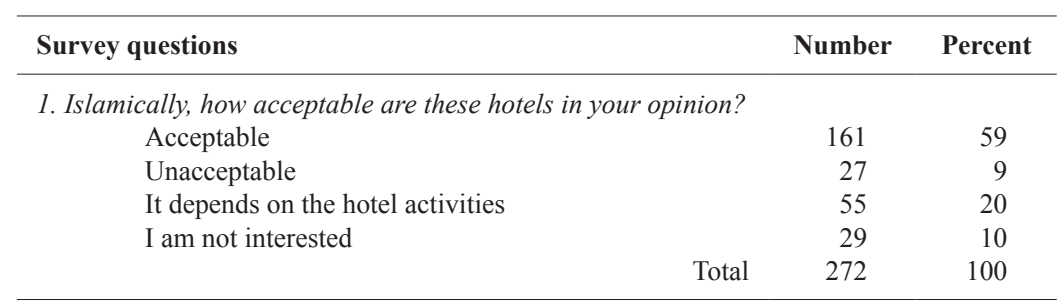




\begin{tabular}{|c|c|c|c|}
\hline \multicolumn{4}{|l|}{ 2. Is vacation a need? } \\
\hline It is a need & \multirow{4}{*}{\multicolumn{2}{|c|}{ Total }} & 66 \\
\hline It is unnecessary & & & 22 \\
\hline \multirow[t]{2}{*}{ Commercial activity } & & & 29 \\
\hline & & & 100 \\
\hline \multicolumn{4}{|c|}{ 3. What are your priorities when you choose a vacation?* } \\
\hline Price & & 532 & 82 \\
\hline Cleanliness & & 289 & 45 \\
\hline Quality of service & & 275 & 42 \\
\hline Proximity to sea & & 226 & 35 \\
\hline Location & & 210 & 32 \\
\hline Food and beverage & & 205 & 31 \\
\hline Number of stars the hotel has (image) & & 116 & 18 \\
\hline Entertainment (Animation activities) & & 102 & 15 \\
\hline Hotel capacity & & 91 & 14 \\
\hline \multicolumn{4}{|l|}{ 4. How do you rate the prices of Islamic hotels? } \\
\hline Reasonable & & 50 & 20 \\
\hline Expensive & & 139 & 57 \\
\hline \multirow[t]{2}{*}{ Moderate } & & 56 & 23 \\
\hline & Total & 245 & 100 \\
\hline \multicolumn{4}{|l|}{ 5. Do you vacation in winter? } \\
\hline Yes - regularly & & 76 & 24 \\
\hline No & & 121 & 38 \\
\hline \multirow{2}{*}{ Sometimes } & & 110 & 35 \\
\hline & Total & 317 & 100 \\
\hline \multicolumn{4}{|c|}{ 6. Do you keep your religious sensitivity when you are on } \\
\hline \multicolumn{4}{|c|}{ vacation? } \\
\hline & & 110 & 22 \\
\hline \multirow{2}{*}{$\begin{array}{l}\text { I ignore it a little bit } \\
\text { I lose sensitivity to a greater extent }\end{array}$} & & 35 & 7 \\
\hline & Total & 501 & 100 \\
\hline \multicolumn{4}{|c|}{ 7. Are the number of Islamic hotels adequate in Turkey? } \\
\hline Adequate & & NA & 91 \\
\hline Not adequate & & & 3 \\
\hline \multirow[t]{2}{*}{ Haven't heard of such hotels } & & & 6 \\
\hline & Total & & 100 \\
\hline \multicolumn{4}{|l|}{ 8. How do you spend your time at the hotel?* } \\
\hline Swimming & & NA & 89 \\
\hline Sun tanning & & & 53 \\
\hline Sport activities & & & 36 \\
\hline Sauna - Turkish hamam & & & 29 \\
\hline Chatting & & & 27 \\
\hline Drinking something at the lobby/bar & & & 23 \\
\hline Sleeping & & & 19 \\
\hline Watching TV & & & 14 \\
\hline Internet surfing & & & 11 \\
\hline Other & & & 32 \\
\hline
\end{tabular}


9. Which destination is your favourite destination?

Didim-Alanya-Ayvalık-Kemer 894

Fethiye-Kusadasi-Bodrum-Marmaris-Side- Belek-

Manavgat-Kas

66

$\begin{array}{lll}\text { Total } & 1358 & 100\end{array}$

(Source: http://www.islamioteller.net/

* Multiple answers were allowed. NA: Numbers are not available)

\section{Conclusion and Recommendations}

The purpose of this article was to propose a conceptual framework for the Islamic tourism concept and to comment on the Turkish halāl tourism industry. My analysis of previous literature shows that there seems to be an ambiguity about the definition of the Islamic tourism concept. Commentators and authors take differing stands on the definition and the scope of the concept. In this contribution, I propose a motivational approach to the concept and argue that Islamic tourism is currently somewhat more of a philosophical discussion. More specifically, the word Islamic renders the question of what is Islamic and what is not.

- Therefore, I propose a definition that takes "Islamically acceptable" motivations as the reference point.

- I also propose to use the term halāl to describe the economy and the sector where haläl goods and services are offered to the markets. In brief, Islamic tourism represents the demand side (e.g., participants and their motivations) whereas halāl tourism represents the supply side, with sectors, goods and services offered for consumption.

- Islam and tourism are multidisciplinary areas. Therefore, a joint effort is needed to deepen the discussion on Islam and tourism. Academicians from the fields of Islamic studies and tourism as well as other related areas should get together and create an edited book that discusses different sides of the concept and offers conceptualisations from their own perspectives.

There is too much information pollution about Islam, Muslims and the "Islamic way of life" today and proper academic work will diminish the effects of this pollution. On the practitioners' side, certification and accreditation practices are important to provide standards, high-quality halāl goods and services for markets. The World Halal Forum, initially referred to, and recently held in Kuala Lumpur, brought practitioners together to talk about certification and standardisation in the halāl industry. Practitioners should get together in fairs and support research to better understand the expectations of Muslim consumers. 


\section{Notes}

1. P. Kotler and N. Armstrong, Principles of Marketing (Upper Saddle River NJ: Pearson, 2010, $9^{\text {th }}$ ed.); R. L. Oliver, "Value as Excellence in the Consumption Experience," in M. B. Holbrook (ed.), Consumer Value: A Framework for Analysis and Research (New York: Routledge, 1999), 43-63; M. B. Holbrook, "Introduction to Consumer Value," in Holbrook (ed.), Consumer Value, 1-29.

2. V. A. Zeithaml, "Consumer Perceptions of Price, Quality and Value: A Means-End Model and Synthesis of Evidence," Journal of Marketing 52 (July 1988), 2-22.

3. Oliver, "Value."

4. C. Goeldner and B. Ritchie, Tourism: Principles, Practices, Philosophies (Hoboken NJ: John Wiley, 2010, $10^{\text {th }}$ ed.), 12.

5. S. Medlik, Dictionary of Travel, Tourism and Hospitality (Oxford: Butterworth-Heinemann, 2003, $3^{\text {rd }}$ ed.)

6. Ibid.

7. S. J. Page and J. Connell, Tourism: A Modern Synthesis (London: Thomson Learning, 2009, $3^{\text {rd }}$ ed.).

8. Ibid., 4.

9. Ibid., 65, and R. A. Chadwick, "Concepts, Definitions and Measurement Used in Travel and Tourism Research," in J. R. Brent Ritchie and C. Goeldner (eds.), Travel Tourism and Hospitality Research: A Handbook for Managers and Researchers (Hoboken NJ: John Wiley, 1995, $2^{\text {nd }}$ ed.), 65.

10. Page and Connell, Tourism, 9.

11. K. Din, "Islam and Tourism: Patterns, Issues, and Options," Annals of Tourism Research 16 (1989), 542-63; A. Ala-Hamarrneh, A. and C. Steiner, "Islamic Tourism: Rethinking the Strategies of Tourism Development in the Arab World after September 11, 2001," Comparative Studies of South East 24, no. 1 (2004), 173-82; N. Scott and J. Jafari (eds.), Bridging Tourism Theory and Practice: Tourism in the Muslim World (Emerald Group Publishing, 2010), available online at http://www. emeraldinsight.com/books.htm?issn=2042-1443\&volume=2 (accessed on 14 June 2012), vol. 2; M. I. Kalesar, "Developing Arab-Islamic Tourism in the Middle East: An Economic Benefit or a Cultural Seclusion?” International Politics 3, no. 5 (2010), 105-36; H. Zamani-Farahani and J. C. Henderson, "Islamic Tourism and Managing Tourism Development in Islamic Societies: The Cases of Iran and Saudi Arabia," International Journal of Tourism Research 12 (2010), 79-89; A. AlaHamarneh, "Islamic Tourism: A Long Term Strategy of Tourist Industries in the Arab World after 9/11 (Centre for Research on the Arab World, 2011), available online at http://www.staff.uni-mainz. de/alhamarn/Islamic\%20Tourism\%20-\%20paper\%20for\%20BRISMES\%202004.htm (accessed on 23 June 2011); J. C. Henderson, "Tourism Destination Development: The Case of Malaysia," Tourism Recreation Research 33 (2008), 49-58; idem, "Representations of Islam in Official Tourism Promotion," Tourism, Culture and Communication 8 (2008), 135-46; idem, "Islamic Tourism Reviewed," Tourism Recreation Research 34, no. 2 (2009), 207-12; idem, "Islam and Tourism," in Scott and J. Jafari (eds.), Bridging, 75-89.

12. Henderson, "Islam and Tourism."

13. Ibid.

14. Ala-Hamarneh, "Islamic Tourism."

15. "Islamic Tourism Reviewed."

16. A. S. Shakiry, "The Academy of Islamic Tourism Project," Islamic Tourism 25 (September-October 2006), available online at http://www.itm-itw.com/Articles/articles.php?issue $=25$ (accessed on 23 June 2011).

17. A. R. Hassan, "Islamic Tourism Revisited," Islamic Tourism 32, no. 2 (2007).

18. Idem, "Islamic Tourism: The Concept and the Reality," Islamic Tourism 14, no. 2 (2004).

19. M. Doğan, “Türkiye'de islami turizm ingelişimi: 2002-2009,” in: İ. Şiriner, F. Morady, J. Mika, M. Aydın, Ş. A. Koç, H. Kapucu, and E. Doğan (eds.), Political Economy, Crises and Development (Istanbul: IJOPEC Publication, 2011), 471-87.

20. Sah̆̄ al al-Bukhārī (2011), transl. M. Muhsin Khan, available online at http://www.searchtruth.com/ book_display.php?book=1\&translator=1 (accessed on 14 June 2011). 
21. Din, "Islam" (an excellent review of the Islamic perspective on travel and tourism).

22. Ibid.

23. Ibid., 551-52.

24. B. Aglamaz, "Islam'da seyahat etmek" [Tavelling in Islam] (2009), available online at www. antalyamuftulugu.gov.tr/hutbeler/2009_temmuz_hutbeleri.doc (accessed on 20 June 2011).

25. Zamani-Farahani and J. C. Henderson, "Islamic Tourism."

26. Diyanet Isleri Baskanligi, "Helal" [The Halāl] (2011), available online at http://www.diyanet.gov.tr/ turkish/dy/DiniBilgilerDetay.aspx?ID=1884 (accessed on 17 June 2011).

27. F. Gülen, "Helal lokma ve iffetli nesiller" [Halāl Bite and Virtuous Generations] (2011), available online at http://www.herkul.org/kiriktesti/index.php?view=article\&article_id=4597 (accessed on 17 June 2011).

28. Ibid.

29. A. R. Hassan, "Islamic Tourism: A Matter of Faith," Islamic Tourism 33 (2008), 2; "Halaltrip" (2011), available online at http://www.halaltrip.com/home.php (accessed on 4 June 2011); Wikipedia (2011), available online at http://en.wikipedia.org/wiki/Halal_tourism (accessed on 17 June 2011).

30. Kotler and Armstrong, Principles; E. Sirakaya and A. G. Woodside, "Building and Testing Theories of Decision Making by Travelers, Tourism Management 26 (2005), 815-32.

31. Goeldner and Ritchie, Tourism.

32. Din, "Islam."

33. Ibid.

34. M. Oppermann, "Sex Tourism," Annals of Tourism Research, 26, no. 2 (1999), 251-66.

35. M. Howley and J. van Westering, "Developing Wine Tourism: A Case Study of the Attitude of English Wine Producers to Wine Tourism," Journal of Vacation Marketing 14 (2008), 87-95.

36. Oliver, "Value"; Zeithaml, "Consumer."

37. D. A. Baker and J. L. Crompton, "Quality, Satisfaction and Behavioral Intentions," Annals of Tourism Research 27, no. 3 (2000), 785-804.

38. Goeldner and B. Ritchie, Tourism.

39. M. Kozak, "Comparative Analysis of Tourist Motivations by Nationality and Destinations," Tourism Management 23 (2002), 221-32.

40. C. Ryan and I. Glendon, "Application of Leisure Motivation Scale to Tourism," Annals of Tourism Research 25, no. 1 (1998), 169-84.

41. H. Bansal and H. A. Eiselt, "Exploratory Research of Tourist Motivations and Planning," Tourism Management 25 (2004), 387-96.

42. Din, "Islam."

43. Aglamaz, "Islam'da."

44. B. Kusursuz, "Bir demet gezi adabı mülahazası" (2011), available online at http://www.herkul.org/ yazarlar/index.php?view=article\&article_id=3759 (accessed on 2 July 2011).

45. Holbrook, "Introduction;" Oliver, "Value;" J. Alegre and J. Garau, "Tourist Satisfaction and Dissatisfaction," Annals of Tourism Research 37, no. 1 (2009), 52-73.

46. Zeithaml, "Consumer;" T. Duman A. Mattila, "The Role of Affective Factors on Perceived Value: An Examination in an Experiential Service Environment," Tourism Management 26, no. 3 (2005), $311-23$

47. Oliver, "Value."

48. Zamani-Farahani and Henderson, "Islamic Tourism," 80-81.

49. N. H. Hashim, J. Murphy, and N. M. Hashim, "Islam and Online Imagery on Malaysian Tourist Destination Websites," Journal of Computer-Mediated Communication 12 (2007), 1082-1102.

50. According to the Ministry of Culture and Tourism, 2011, available online at www.tourism.gov.tr (accessed on17 June 2011).

51. T. Duman and C. Tosun, "Current Developments in Turkish Tourism," Anatolia: An International Journal of Tourism and Hospitality Research 21, no. 1 (2010), 5-9 [Editorial].

52. Ibid.

53. Ibid. 
54. M. Doğan, "Türkiye'de."

55. Y.Aktay, Modernlesme ve gelenek baglaminda dini bilgi ve otoritenin dönüsümü [Modernism and the Transformation of Religious Knowledge and Authority within Culture] (Istanbul: IletisimYayinlari, $2005,2^{\text {nd }}$ ed. $), 345$.

56. Ibid.

57. Turizmgazetesi.com, "İslami turizm serbest bölgesi bile düşünülüyor da...” (2005), available online at http://www.turizmgazetesi.com/articles/article.aspx?id=30707 (accessed on 16 June 2012).

58. Turizmhaberleri, "Tesettür turizmi dosyasi [Veiled Tourism File] (2011), available online at http:// www.turizmhaberleri.com/haberayrinti.asp?ID=13137 (accessed on 20 June 2011).

59. Turizmhaberleri, "Tesettür."

60. Ibid.

61. Doğan, "Türkiye'de."

62. T. Duman and M. Kozak, "The Turkish Tourism Product: Differentiation and Competitiveness," Anatolia: An International Journal of Tourism and Hospitality Research 21, no. 1 (2010), 89-106.

63. Bugun, " 500,000 kisinin sifa kaynagi Turkiye" [Healing source for 500,000 is Turkey] (2011), available online at http://www.bugun.com.tr/haber-detay/157823-turkiye-yuzbinlerin-sifa-kaynagihaberi.aspx (accessed on 7 June 2011).

64. Doğan, "Türkiye'de." 